\title{
Trisomy E (18) Syndrome: Clinical Spectrum in 12 New Cases, including Chromosome Autoradiography in $4^{*}$
}

\author{
FELICE M. WEBER and ROBERT S. SPARKES†
}

From the Department of Pediatrics and Medicine, UCLA School of Medicine, Los Angeles, California 90024, USA

The trisomy E (18) syndrome, first described by Edwards et al. (1960), is characterized by failure to thrive, narrow elongated skull with prominent occiput, micrognathia, low set ears, a short sternum, overlap of the middle fingers by the index and fifth fingers, rockerbottom feet with talipes calcaneovalgus and a prominent calcaneum, and the dermatoglyphic findings of an increased number of digital arch patterns with the palmar axial triradius in the $\mathbf{t}^{\prime}$ position (Uchida, Patau, and Smith, 1962). Though earlier studies were inconclusive as to whether the extra chromosome was a No. 17 (Gottlieb et al., 1962) or a No. 18 (Patau, 1965), there is now general agreement that trisomy 18 is present. This conclusion has been based primarily on the ability to distinguish morphologically the two chromosome pairs; confirmatory autoradiographic studies have been previously reported on only two cases (Yunis, Hook, and Mayer, 1964; German, 1964). With this report we add the routine chromosome and clinical descriptions in 12 affected individuals plus the chromosome autoradiographic findings in 4 of these patients.

\section{Case Reports}

The specific clinical characteristics which suggest trisomy $E$ (18) for each of our 12 patients are summarized and compared with those from a series by Taylor (1968) in Table I. The birthweight and pertinent pregnancy and family histories are given in Table II. Only three patients have a birthweight greater than $2.5 \mathrm{~kg}$. and none greater than $3.15 \mathrm{~kg}$. The mean maternal age is 30.2 years, and the mean paternal age is 31.4 years.

Necropsy findings in 10 of our 12 deceased patients

Received 8 January 1970.

* Supported in part by a grant from the Division of Mental Retardation, Social and Rehabilitation Service, Department of Health, Education and Welfare, and by California State Department of Mental Hygiene Grant.

t Send reprint requests to Robert S. Sparkes, M.D., Department of Medicine, UCLA School of Medicine, Los Angeles, California 90024, U.S.A. are summarized in Table III; Case 12 died at 4 months and Case 8 at $5 \frac{1}{2}$ months without necropsy. In addition to the findings in Table I, 3 patients had limited hip abduction, 2 patients had hypotonia, 2 had partial syndactyly, 2 had a single palmar crease, 2 had abnormal shoulder abduction, and 2 had an inguinal hernia. Individual patients were noted to have jaundice, hypertonia, microcephaly, 'jitteriness and apnoea,' harelip, short neck, hypoplastic nails, long hyperconvex nails, and a short dorsiflexed great toe.

\section{Cytogenetic Studies}

Chromosome analysis on blood lymphocytes (Arakaki and Sparkes, 1963) shows that all 12 patients have a modal count of 47 chromosomes with a normal sex chromosome complement plus the extra chromosome in the $\mathrm{E}$ group, which appears morphologically most like a No. 18 .

The autoradiographic findings (Schmid, 1963) on the E group chromosomes from 4 patients are shown in the Fig. In each case the morphologically small short arms and the heavy labelling of the extra chromosome indicate trisomy for chromosome 18. The autoradiographic study on Case 7 was from skin fibroblasts cultured with a modified method of Tjio and Puck (1958).

\section{Discussion}

Though patients with the same chromosome syndrome may not have identical physical anomalies, they usually have a sufficient number of phenotypic aberrations in common to permit their classification into a specific syndrome (Warkany, Passarge, and Smith, 1966). This clinical heterogeneity in the trisomy $\mathrm{E}$ (18) syndrome is demonstrated by the clinical observations and necropsy findings in our 12 cases (Table I). Only Case 5 did not present with the usual clinical features. However, Passarge and colleagues (1966) have described a similar girl with hydrocephalus, lumbar meningomyelocele and congenital heart disease, and they also noted reports of four additional cases with hydrocephalus, all with chromosomal findings indicative of trisomy $\mathrm{E}$ (18). 
TABLE I

CLINICAL FINDINGS IN OUR 12 CASES OF TRISOMY E(18)

\begin{tabular}{|c|c|c|c|c|c|c|c|c|c|c|c|c|c|c|c|}
\hline \multirow{2}{*}{ Characteristics } & \multicolumn{12}{|c|}{ Case No. } & \multicolumn{3}{|c|}{ Percentage } \\
\hline & 1 & 2 & $3 *$ & 4 & $5^{*}$ & $6^{*}$ & 7 & 8 & 9 & 10 & 11 & 12 & $\begin{array}{l}\text { In Our } \\
\text { Cases }\end{array}$ & In & $\begin{array}{l}\text { aylor's } \\
\text { (1968) }\end{array}$ \\
\hline Sex & $\mathbf{F}$ & F & $\mathbf{F}$ & $\mathbf{F}$ & $\mathbf{F}$ & $\mathbf{M}$ & $\mathbf{F}$ & $\mathbf{F}$ & $\mathbf{M}$ & F & $\mathbf{M}$ & F & $\begin{array}{ll}\mathrm{F} & 75 \\
\mathrm{M} & 25\end{array}$ & $\mathbf{F}$ & $\begin{array}{l}81 \cdot 5 \\
18 \cdot 5\end{array}$ \\
\hline Failure to thrive & + & + & + & + & + & + & + & + & + & + & + & + & 100 & & 96 \\
\hline Micrognathia & + & + & + & + & $?$ & + & + & + & + & + & + & + & 100 & & 92 \\
\hline Arches on fingertips (five or more) & + & $?$ & + & + & $?$ & $?$ & $?$ & $?$ & + & + & ? & + & 100 & & 96 \\
\hline Short sternum & + & + & + & $?$ & $?$ & $?$ & $?$ & $?$ & + & + & + & + & 100 & & 68 \\
\hline Low set ears & + & + & + & + & $?$ & + & + & + & + & + & + & + & 100 & & $91 \cdot 8$ \\
\hline Congenital heart disease & + & + & + & + & + & + & + & + & + & $\overline{1}$ & + & + & $\begin{array}{l}92 \\
90\end{array}$ & & $\begin{array}{l}85 \\
89\end{array}$ \\
\hline & - & + & + & + & $?$ & $\begin{array}{l}+ \\
+\end{array}$ & + & + & $\begin{array}{l}+ \\
+\end{array}$ & + & $\stackrel{?}{-}$ & + & $\begin{array}{l}90 \\
67\end{array}$ & & $\begin{array}{r}89 \\
100\end{array}$ \\
\hline Elongated skull & + & + & + & - & - & - & - & + & + & + & + & + & 67 & & 93 \\
\hline Microphthalmos & - & + & - & - & - & + & + & + & - & + & ? & + & 55 & & 29 \\
\hline Prominent calcaneus & + & + & + & - & - & + & - & $?$ & + & - & - & + & 55 & & 77 \\
\hline Calcaneo-valgus feet & + & + & + & - & - & + & - & - & + & - & - & + & 50 & & 52 \\
\hline Equino-varus feet & - & - & - & - & + & - & + & + & - & - & + & - & 49 & & 8 \\
\hline Malformed ears & + & - & - & + & $?$ & + & - & - & + & - & - & + & 45 & & 88 \\
\hline
\end{tabular}

$+=$ present; $-=$ absent; ? = not recorded.

* In addition, Case 6 had cleft palate; Case 5 had hydrocephalus, cleft palate, and congenital dislocation of the hips; and Case 3 had congenital dislocation of the hips.

TABLE II

PREGNANCY HISTORIES, BIRTHWEIGHTS

AND FAMILY HISTORIES IN OUR 12 PATIENTS WITH TRISOMY E(18)

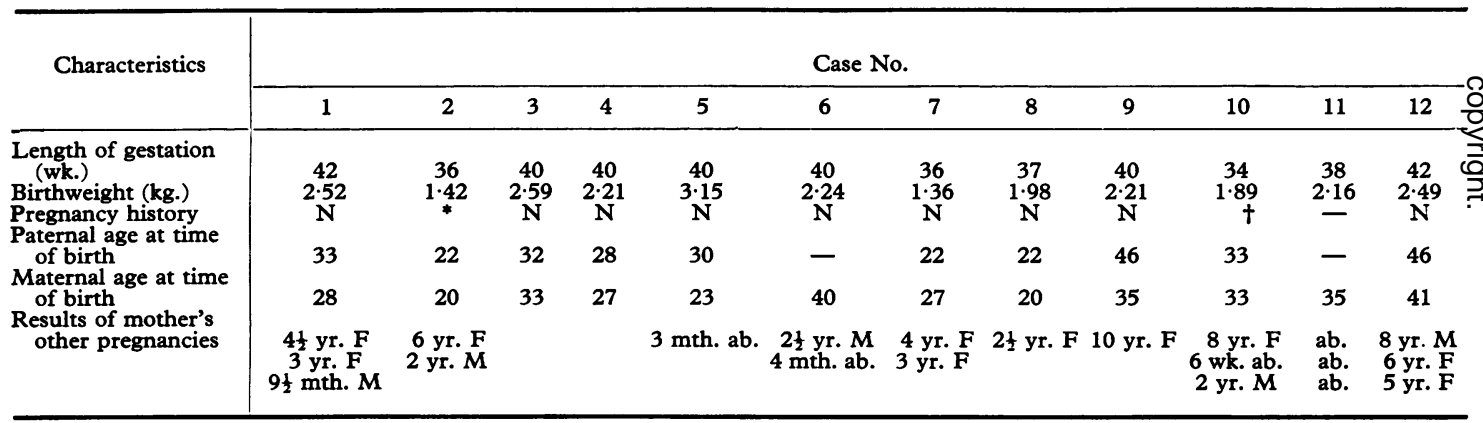

$\mathrm{N}=$ normal $\mathrm{M}=$ male $; \mathrm{F}=$ female $; \mathrm{ab} .=$ spontaneous abortion; $*$ = polyhydramnios; $t=$ flu-like syndrome.

TABLE III

NECROPSY FINDINGS ON 10 OF OUR PATIENTS WITH TRISOMY E(18)

\begin{tabular}{|c|c|c|c|c|c|c|c|c|c|c|c|c|}
\hline \multirow{2}{*}{ Characteristics } & \multicolumn{10}{|c|}{ Case No. } & \multicolumn{2}{|c|}{$\begin{array}{c}\text { Percentage } \\
\text { with } \\
\text { Characteristic }\end{array}$} \\
\hline & 1 & 2 & 3 & 4 & 5 & 6 & 7 & 9 & 10 & 11 & $\begin{array}{l}\text { Our } \\
\text { Cases }\end{array}$ & $\begin{array}{c}\text { Taylor's } \\
\text { Cases } \\
\text { (1968) }\end{array}$ \\
\hline $\begin{array}{l}\text { Sex } \\
\text { Age at death } \\
\text { Ventricular septal defect } \\
\text { Superficially normal brain } \\
\text { Persistent ductus arteriosus } \\
\text { Renal anomaly } \\
\text { Normal renal tract } \\
\text { Horseshoe kidney } \\
\text { Meckel's diverticulum } \\
\text { Major atrial septal defect } \\
\text { Coarctation of aorta } \\
\text { Normal heart } \\
\text { Hydronephrosis }\end{array}$ & $\begin{array}{l}\text { F } \\
60 \mathrm{hr} \\
+ \\
+ \\
\overline{+} \\
= \\
- \\
- \\
- \\
- \\
-\end{array}$ & $\begin{array}{l}\text { F } \\
\text { dy. } \\
+ \\
+ \\
+ \\
+ \\
+ \\
+ \\
+ \\
+ \\
+\end{array}$ & $\begin{array}{l}\text { F } \\
4 \text { mth. } \\
+ \\
+ \\
+ \\
+ \\
- \\
+ \\
+ \\
- \\
- \\
-\end{array}$ & $\begin{array}{l}\text { F } \\
\mathbf{\text { wk. }} \\
+ \\
+ \\
- \\
\overline{+} \\
+ \\
- \\
- \\
- \\
= \\
-\end{array}$ & $\begin{array}{l}\text { F } \\
\text { mth. } \\
+ \\
+ \\
+ \\
+ \\
+ \\
+ \\
- \\
- \\
- \\
-\end{array}$ & $\begin{array}{l}\text { M } \\
2 \text { wk. } \\
+ \\
+ \\
+ \\
\overline{+} \\
- \\
= \\
- \\
- \\
-\end{array}$ & $\begin{array}{c}\mathbf{F} \\
\mathbf{8 k} . \\
+ \\
+ \\
+ \\
+ \\
- \\
+ \\
+ \\
+ \\
- \\
- \\
-\end{array}$ & $\begin{array}{c}\text { M } \\
10 \text { wk. } \\
+ \\
+ \\
+ \\
\overline{+} \\
= \\
- \\
- \\
- \\
- \\
-\end{array}$ & $\begin{array}{c}\text { F } \\
4 \frac{1}{2} \text { mth. } \\
\bar{t} \\
\overline{-} \\
\overline{+} \\
= \\
- \\
\overline{-} \\
+ \\
-\end{array}$ & $\begin{array}{c}\text { M } \\
5 \text { wk. } \\
+ \\
+ \\
- \\
+ \\
- \\
- \\
- \\
- \\
-\end{array}$ & $\begin{array}{l}90 \\
80 \\
60 \\
50 \\
50 \\
30 \\
30 \\
20 \\
10 \\
10 \\
10\end{array}$ & $\begin{array}{c}47 \\
92 \\
53 \\
62 \\
33 \\
23 \\
40 \\
31 \\
6 \cdot 2 \\
29 \\
23\end{array}$ \\
\hline
\end{tabular}

$+=$ present; $-=$ absent; $*$ = hydrocephalus and lumbar meningomyelocele; $\dagger=$ brain-stem induration. 


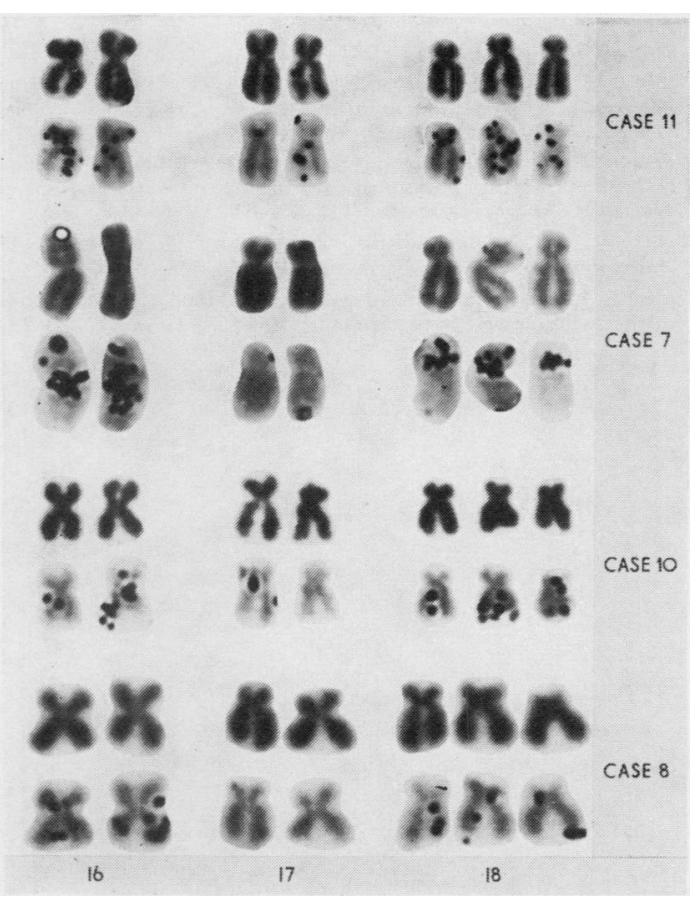

FIg. The E group chromosomes from 4 patients with trisomy E (18). For comparison, the autoradiographically labelled chromosomes are placed below the regularly prepared chromosomes from the same cell. Results for Cases 11, 10, and 8 are from blood lymphocyte cultures, and for Case 7 from a skin fibroblast culture.

The sex ratio of 9 females to 3 males in our series agrees with the previously described preponderance of females with this syndrome. Chromosome studies of abortuses and stillbirths (Taylor, 1968) do not indicate that this greater proportion of females is due to increased mortality of affected male fetuses. However, our 3 male patients did die at a younger age than the females, lending support to the suggestion of Weber (1967) that one reason for the apparently greater number of females with trisomy E (18) may be that affected males die younger and perhaps before the diagnosis is suspected or confirmed by chromosome analysis.

The mean maternal age of 30.2 years for our group of patients is in keeping with previous suggestions of a high maternal age; and the mean paternal age of 31.4 would correlate secondarily with the mean maternal age. Taylor (1968) gives a mean maternal age of 31.7 years and a mean paternal age of 34.9. She also notes that unpublished data by Magenis and Hecht (1967) reveal a bimodal distribution of maternal ages in mothers of children with trisomy $\mathrm{E}$ (18), very similar to that seen in Down's syndrome with two modes, one at 20-24 years and the other at 35-39 years of age.
Chromosome 18 is distinguished morphologically from chromosome 17 primarily by its smaller short arms. Patau (1965) suggested that the extra chromosome was a No. 18 based upon these morphologically small short arms in 3 of the 5 chromosomes in the 17-18 group in one case of trisomy E. A similar interpretation of the cytogenetic findings is also made for each of our patients.

Autoradiographic chromosome studies with tritiated thymidine in normal persons indicate that the No. 17 replicates relatively early in the cell cycle and the No. 18 later, so that No. 18 shows heavy labelling and No. 17 shows little labelling (Gilbert et al., 1962; Schmid, 1963). The two previously reported cases of trisomy $\mathrm{E}$ with autoradiographic chromosome analysis both show three late labelling chromosomes, indicating the extra chromosome is a No. 18 (Yunis et al., 1964; German, 1964). The late labelling autoradiographic pattern of the trisomic chromosome in our 4 patients confirms these earlier observations (Fig.). The autoradiographs on Case 7 represent the first reported findings on skin fibroblasts in this syndrome and are compatible with results from the blood studies on the other patients.

\section{Summary}

The clinical and necropsy findings in 12 newly described cases of trisomy $\mathrm{E}$ (18) are given to show the clinical heterogeneity of this syndrome. The trisomic chromosome appears to be a No. 18, based on the morphology of the routinely prepared chromosomes from blood lymphocytes and also upon the late labelling demonstrated in the autoradiographic chromosomes studies in 4 of these patients, 3 of which were done on blood lymphocytes and the fourth on skin fibroblasts.

We thank Dr. Helga Muller for autoradiographic studies and Mrs. Iris Veomett for cytogenetic technical assistance.

\section{REFERENCES}

Arakaki, D. T., and Sparkes, R. S. (1963). Microtechnique for culturing leukocytes from whole blood. Cytogenetics, 2, 57-60.

Edwards, J. H., Harnden, D. G., Cameron, A. H., Cross, V. M., and Wolf, O. H. (1960). A new trisomic syndrome. Lancet, 1, 787790.

German, J. (1964). The pattern of DNA synthesis in the chromosomes of human blood cells. Fournal of Cell Biology, 20, 37-58.

Gilbert, C. W., Muldal, S., Lajtha, L. G., and Rowley, J. (1962). Time-sequence of human chromosome duplication. Nature (London), 195, 869-873.

Gottlieb, M. I., Hirschhorn, K., Cooper, H. L., Lusskin, N., Moloshok, R. E., and Hodes, H. L. (1962). Trisomy 17 syndrome. Report of three cases and review of literature. American fournal of Medicine, 33, 763-773. 
Passarge, E., True, C. W., Sueoka, W. T., Baumgartner, N. R., and Keer, K. R. (1966). Malformations of the central nervous system in trisomy 18 syndrome. Fournal of Pediatrics, 69, 771-778.

Patau, K. (1965). Identification of chromosomes. In Human Chromosme Methodology, pp. 155-186. Ed. by J. J. Yunis. Academic Press, New York.

Schmid, W. (1963). DNA replication patterns of human chromosomes. Cytogenetics, 2, 175-193.

Taylor, A. (1968). Autosomal trisomy syndromes: a detailed study of 27 cases of Edward's syndrome and 27 cases of Patau's syndrome. Fournal of Medical Genetics, 5, 227-252.

Tjio, J. H., and Puck, T. T. (1958). The somatic chromosomes of man. Proceedings of the National Academy of Sciences of the United States of America 44, 1229-1237.

Uchida, I. A., Patau, K., and Smith, D. W. (1962). Dermal patterns of 18 and $\mathrm{D}_{1}$ trisomics. American fournal of Human Genetics, 14, 345-352.

Warkany, J., Passarge, E., and Smith, L. B. (1966). Congenital $\mathscr{\mathcal { S }}$ malformations in autosomal trisomy syndromes. American fournal of Diseases of Children, 112, 502-517.

Weber, W. W. (1967). Survival and the sex ratio in trisomy 17-18. American fournal of Human Genetics, 19, 369-377.

Yunis, J. J., Hook, E. B., and Mayer, M. (1964). Deoxyribosenucleic-acid replication pattern of trisomy 18 . Lancet, 2, 286-287. 